\title{
Awareness of Post-Exposure Prophylaxis of HIV Among Health Care Personnel in Asella Teaching Hospital, Asella Town, South-East Ethiopia, 2014: Cross Sectional Study
}

\author{
Birhanu Alemu' ${ }^{1}$, Asrat Demessie ${ }^{2}$, Atsede Fantahun ${ }^{3}$, Kahsu Gebrekirstos ${ }^{3}$ \\ ${ }^{1}$ Arsi University, College of Health Sciences, Department of Nursing, Asella, Ethiopia \\ ${ }^{2}$ Addis Ababa University, College of Health Sciences, Department of Nursing and Midwifery, Addis Ababa, Ethiopia \\ ${ }^{3}$ Mekelle University College of Health Science, Department of Nursing, Mekelle, Ethiopia \\ Email address: \\ birhanualemu02@yahoo.com (B. Alemu), asrat.megenta@yahoo.com (A. Demessie), atsedefantahun@gmail.com (A. Fantahun), \\ kahsu75@gmail.com (K. Gebrekirstos)
}

\section{To cite this article:}

Birhanu Alemu, Asrat Demessie, Atsede Fantahun, Kahsu Gebrekirstos. Awareness of Post-Exposure Prophylaxis of HIV Among Health Care Personnel in Asella Teaching Hospital, Asella Town, South-East Ethiopia, 2014: Cross Sectional Study. Clinical Medicine Research. Vol. 4, No. 3, 2015, pp. 69-74. doi: 10.11648/j.cmr.20150403.12

\begin{abstract}
Background: Post-exposure prophylaxis is short-term antiretroviral or immune globulin treatment to reduce the likelihood of viral infection after exposure to the blood or body fluids of an infected person. Timely post-exposure prophylaxis after needle stick exposure to high risk body fluids in work area can reduce the rate of transmission of human immunodeficiency virus significantly. Methods: This institution based cross sectional study was conducted in purposively selected 251 health personnel. Structured questionnaire which was adapted from similar study conducted in Addis Ababa city was used to collect data. Data was analyzed using chi-square test. Ethical clearance was obtained from Addis Ababa University, College of Health Sciences, Department of Nursing and Midwifery. Results: From the total study participants $88.8 \%$ respondents had information about post-exposure prophylaxis and $85.7 \%$ know presence of post-exposure prophylaxis in their hospital. In addition to that $48.2 \%$ respondents responded correctly to the use of post-exposure prophylaxis. From the study participants almost half of the non-health professionals didn't know about post-exposure prophylaxis. Conclusion: Out of the total respondents, majority of them had good level of awareness about post exposure prophylaxis.
\end{abstract}

Keywords: Exposure, Prophylaxis, HIV, Health Personnel, Awareness

\section{Introduction}

Human Immunodeficiency Virus/Acquired immunodeficiency syndrome (HIV/AIDS) is being considered as one of the major health problem and occupational health hazard among health care providers (1). Each day, thousands of people around the world experience accidental exposure to blood and other body fluids or tissues while performing their work duties. Health care personnel who have occupational exposure to blood are at risk for HIV infection (2). The number of people infected with HIV continues to increase persistently (3). Exposure to different body fluids has a potential risk of transmission of blood borne pathogens to health care workers (HCWs) (4). They can be exposed to HIV also by needle stick injuries or cuts, blood or fluid splash to their eyes, mouth and damaged skin. Even though the risk of HIV transmission in these ways is extremely low $(<1 \%)$ for all exposures but can be reduced further by appropriate and timely post-exposure management Post-exposure prophylaxis (PEP) (5). Preventing the occurrence of HIV infection resulting from such accidental injuries at work place and the use of HIV PEP is recommended by the world health organization (WHO) (6).

Although avoiding contact with infected blood is one of the primary strategies of preventing occupationally acquired HIV infection, appropriate PEP is an important element in workplace safety.PEP is short-term antiretroviral or immune globulin treatment to reduce the likelihood of viral infection after exposure to the blood or body fluids of an infected person (1). The prescription PEP following significant potential exposure to HIV has now become routine and it is important that individuals with potential risk of exposure are aware of the procedures to follow and where their first point of contact should be if an incident occurs (7). 
It is necessary to initiate the prophylaxis measure in order to minimize the chance of HIV establishment. Timely PEP after needle stick exposure to high risk body fluids can reduce the rate of transmission significantly. So it is important to determine awareness of individuals about the accidental exposure to HIV infection and PEP particularly in hospitals because much number of staffs and increased risks of acquiring HIV infection (1).The knowledge of risk factors and the circumstances in which these exposures occur in hospitals can be very useful for developing proper preventive guidelines and educational programs (8).Hence, Ethiopia has developed guideline on the prevention of infection in health institutions in July 2004 and also employed since the implementation of free antiretroviral therapy (ART) in January 2005 (1).

Therefore the objective of this study was to determine Awareness of PEP of HIV Infection among health care personnel in Asella Teaching hospital, South-east Ethiopia.

\section{Methods and Materials}

This institution based cross sectional study was conducted in Asella hospital, South-east Ethiopia from December 2013 to may 2014. A total of 251 health care personnel were included in the study. To select study participants' purposive sampling was used. Health care professionals who participated in the study were grouped based their similarity of activities as; physicians and health officers, nurses and midwifery, laboratory and pharmacy, cleaners and porters, maintenance \& laundry workers and rest of them were included under others such as anesthetist, radiologist, physiotherapies and ophthalmologist. Data was collected using structured questionnaire that is adapted from similar study conducted in Addis Ababa city. The questionnaires composed of different variables related to the objective of the study and it was pretested on $5 \%$ similar population which were not included in the study before the actual data collection period. Two diploma nurses and one BSc nurse supervisor was used to collect data and the principal investigator followed the overall data collection process. Every day the questionnaires were checked for completeness and consistency by the supervisor and principal investigator. The necessary feedback was given every morning before the actual procedure. After checking data was coded, entered into EPI INFO and exported to SPSS statistical software version 20.0. Appropriate descriptive statistics (frequency, mean, standard deviation) was calculated and chi-square test was used to determine the association between dependent and independent variables. Ethical clearance was obtained from Addis Ababa University, College of Health Sciences, Department of Nursing and Midwifery. Prior to interview written consent was obtained also from Asella teaching Hospital as well as informed verbal consent was obtained from each respondent after providing adequate information on the purpose of study. Participation in this study was voluntary based and every participant had the right to withdraw from the interview at any time. To ensure the confidentiality no personal identifiers was used.

\section{Results}

\subsection{Socio-Demographic Characteristics of the Study Population}

Out of 251 respondents in the study hospital during the study period a total of $139(55.4 \%)$ were males and the mean age was 31.14 years. Regarding their educational status of respondents $113(45.0 \%)$ were diploma holders. Majority $(67.7 \%)$ of the study participants had work experience of less than 5 years (Table 1).

Table 1. Socio-demographic characteristics of health Care Personnel working in Asella Teaching Hospital, South-east Ethiopia, 2014 (n=251)

\begin{tabular}{|c|c|c|c|}
\hline Variable & & Frequency & Percent \\
\hline \multirow{2}{*}{ Sex } & Male & 112 & 44.6 \\
\hline & Female & 139 & 55.4 \\
\hline \multirow{4}{*}{ Age } & $<25$ & 43 & 17.4 \\
\hline & $25-34$ & 138 & 55.0 \\
\hline & $35-44$ & 49 & 19.6 \\
\hline & $\geq 45$ & 20 & 8.0 \\
\hline \multirow{5}{*}{$\begin{array}{l}\text { Educational } \\
\text { status }\end{array}$} & High school or less & 28 & 11.2 \\
\hline & Certificate & 11 & 4.4 \\
\hline & Diploma & 113 & 45.0 \\
\hline & Bachelor degree & 82 & 32.7 \\
\hline & Masters degree/MD and above & 17 & 6.8 \\
\hline \multirow{5}{*}{ Profession } & Physician and $\mathrm{HO}$ & 55 & 21.9 \\
\hline & Nurse and midwife & 82 & 32.7 \\
\hline & Laboratory and Pharmacy & 26 & 10.4 \\
\hline & $\begin{array}{l}\text { Cleaner, Porters and Laundry } \\
\text { workers }\end{array}$ & 51 & 20.3 \\
\hline & Others & 37 & 14.7 \\
\hline \multirow{5}{*}{ Department } & Outpatient department & 50 & 19.9 \\
\hline & Wards & 97 & 38.6 \\
\hline & $\begin{array}{l}\text { Operation theatre \& special } \\
\text { clinic }\end{array}$ & 26 & 10.4 \\
\hline & Maternal service & 22 & 8.8 \\
\hline & Others & 56 & 22.3 \\
\hline \multirow{3}{*}{$\begin{array}{l}\text { Work } \\
\text { experience }\end{array}$} & Less than 5 years & 170 & 67.7 \\
\hline & $5-10$ years & 42 & 16.8 \\
\hline & Above 10 years & 39 & 15.5 \\
\hline
\end{tabular}

\subsection{Risk of Accidental Exposure to HIV Infection}

Majority $206(82.1 \%)$ believed as they were at a risk of acquiring HIV infection and $127(50.6 \%)$ respondents leveled themselves as high risk to HIV infection. From the total participants $64(25.5 \%)$ experienced needle stick or other sharp injuries, among them 45 (17.9\%) experienced injury only one time and $16(6.4 \%)$ had encountered more than two times within their life time.

Majority $199(79.3 \%)$ of the study participants did not take any training related to needle stick injuries or other exposure and about half $(49.4 \%)$ of the health care providers in this study use universal precaution always (Table 2). 
Table 2. Accidental occupational exposure to HIV infection of health Care Personnel working in Asella Teaching Hospital, South-east Ethiopia, 2014 $(n=251)$

\begin{tabular}{|c|c|c|c|}
\hline Variable & & Frequency & Percent \\
\hline \multirow{2}{*}{$\begin{array}{l}\text { Thinking of risk of HIV } \\
\text { infection }\end{array}$} & Yes & 206 & 82.1 \\
\hline & No & 45 & 17.9 \\
\hline \multirow{3}{*}{$\begin{array}{l}\text { Level of risk of HIV } \\
\text { infection of Health care } \\
\text { providers }\end{array}$} & High risk & 127 & 50.6 \\
\hline & Low risk & 99 & 39.4 \\
\hline & No risk & 25 & 10.0 \\
\hline \multirow{2}{*}{$\begin{array}{l}\text { Any history needle stick or } \\
\text { other sharp injuries }\end{array}$} & Yes & 64 & 25.5 \\
\hline & No & 187 & 75.5 \\
\hline \multirow{4}{*}{$\begin{array}{l}\text { Number of injuries ever } \\
\text { encountered }\end{array}$} & Once & 45 & 17.9 \\
\hline & Two times & 16 & 6.4 \\
\hline & $\begin{array}{l}\text { More than } \\
\text { two times }\end{array}$ & 11 & 4.4 \\
\hline & No injury & 179 & 71.3 \\
\hline \multirow{2}{*}{$\begin{array}{l}\text { Blood or body fluid splash } \\
\text { to eye, or mouth }\end{array}$} & Yes & 103 & 41.0 \\
\hline & No & 148 & 59.0 \\
\hline \multirow{2}{*}{$\begin{array}{l}\text { Training on how to report a } \\
\text { needle stick injuries or other } \\
\text { exposure }\end{array}$} & Yes & 52 & 20.7 \\
\hline & No & 199 & 79.3 \\
\hline
\end{tabular}

\begin{tabular}{llll}
\hline Variable & & Frequency & Percent \\
\hline Use universal precaution or & Yes, always & 124 & 49.4 \\
wear personal protective & Yes, & 99 & 39.4 \\
equipments & sometimes & 28 & 11.2 \\
& No & 24 & 9.6 \\
$\begin{array}{l}\text { Ever tested for HIV after } \\
\text { injuries }\end{array}$ & Yes & 227 & 90.4 \\
\hline
\end{tabular}

\subsection{Awareness of Health Care Personnel on PEP}

From the total study participants $223(88.8 \%)$ respondents had ever heard of PEP as well as $215(85.7 \%)$ respondents know presence of PEP in their hospital. In addition to that $121(48.2 \%)$ respondents correctly responded to the use of PEP (to prevent establishment of the virus). One hundred sixty five $(65.7 \%)$ respondents answered correctly for the maximum time to start PEP and 151(60.2) the usual duration (4 weeks) of PEP (Table 3).

From the health personnel almost all (98.2\%) of the physicians or health officers know PEP followed by nurses $86.6 \%$ but almost half $(49 \%)$ of the non-health professionals didn't know about PEP (Figure 1).

Table 3. Awareness of PEP among health Care Personnel working in Asella Teaching Hospital, South-east Ethiopia, 2014(n=251)

\begin{tabular}{|c|c|c|c|}
\hline Variables & & Frequency & Percent \\
\hline \multirow{2}{*}{ Ever heard of PEP of HIV } & Yes & 223 & 88.8 \\
\hline & No & 28 & 11.2 \\
\hline \multirow{2}{*}{ Presence of PEP in this hospital } & Yes & 215 & 85.7 \\
\hline & No & 36 & 14.3 \\
\hline \multirow{5}{*}{ Use of PEP } & Prevent transmission of the virus & 82 & 32.7 \\
\hline & Prevent establishment of the virus & 121 & 48.2 \\
\hline & Curing from the disease & 2 & 0.8 \\
\hline & Prolong the lives of the person & 23 & 9.2 \\
\hline & Do not know & 23 & 9.2 \\
\hline \multirow{5}{*}{ The maximum time to start the first PEP } & 1 hour or less & 20 & 8 \\
\hline & Within 24 hours & 36 & 14.3 \\
\hline & Within 72 hours & 165 & 65.7 \\
\hline & After 3 days & 2 & 0.8 \\
\hline & Do not know & 28 & 11.2 \\
\hline \multirow{5}{*}{ The duration of PEP } & Less than 1 week & 9 & 3.6 \\
\hline & 4 weeks & 151 & 60.2 \\
\hline & More than 4 weeks & 15 & 6.0 \\
\hline & Life long & 38 & 15.1 \\
\hline & Do not know & 38 & 15.1 \\
\hline \multirow{2}{*}{ Participation in any training related to PEP } & Yes & 67 & 26.7 \\
\hline & No & 184 & 73.3 \\
\hline \multirow{3}{*}{ When do you take the training } & Within 1 year & 38 & 15.1 \\
\hline & In the Past 2-3 years & 13 & 5.2 \\
\hline & Before 3 years & 16 & 6.4 \\
\hline \multirow{3}{*}{ Written guidelines/ protocols for PEP } & Yes & 92 & 36.6 \\
\hline & No & 87 & 34.7 \\
\hline & Don’t Know & 72 & 28.7 \\
\hline \multirow{3}{*}{ Posters that remind the availability of PEP } & Yes & 121 & 48.2 \\
\hline & No & 77 & 30.7 \\
\hline & Don’t Know & 53 & 21.1 \\
\hline
\end{tabular}




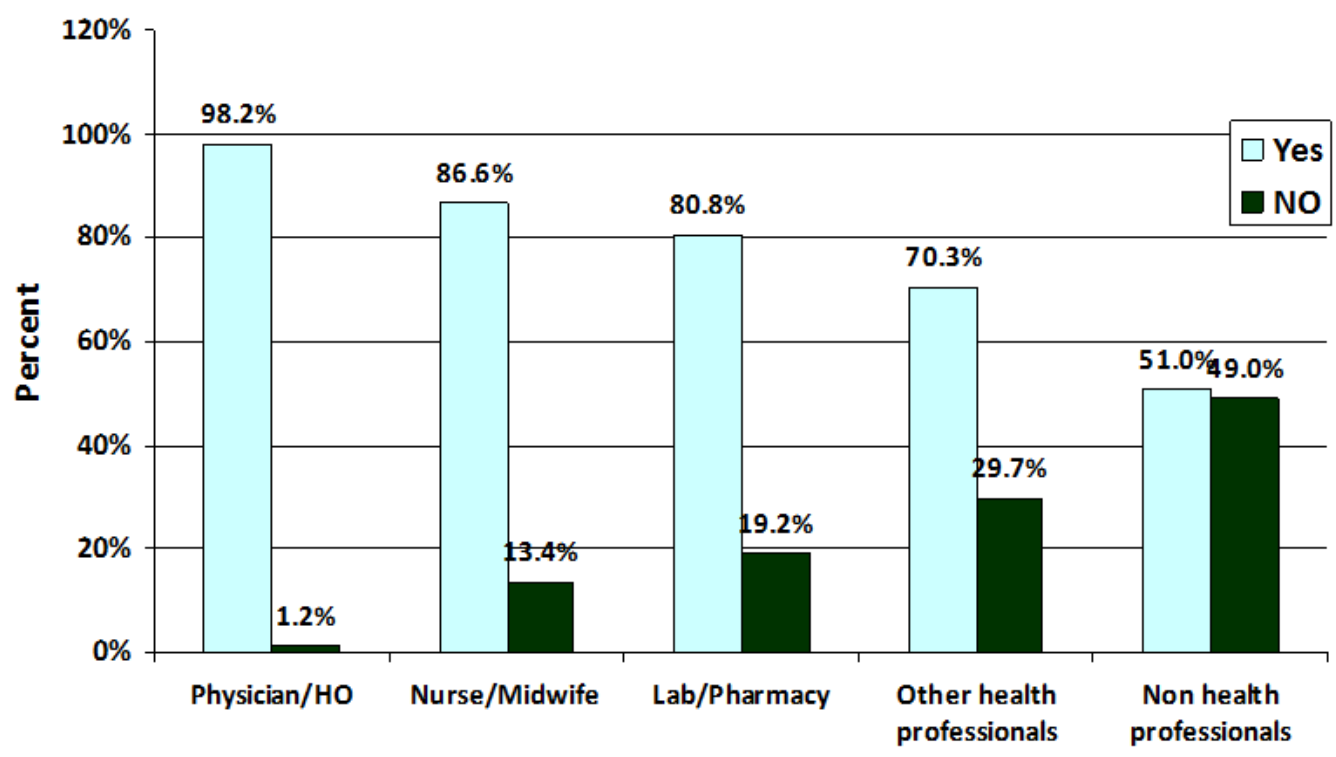

Health care personel

Figure 1. Awareness of health personnel on post exposure prophylaxis in Asella Teaching Hospital, South-east Ethiopia, 2014 (n=251)

Table 4. Association between socio-demographic characteristics and Awareness PEP among health care personnel in Asella Teaching hospital, South-east Ethiopia, $2014(n=251)$

\begin{tabular}{|c|c|c|c|c|c|}
\hline \multirow[b]{2}{*}{ Variables } & & \multicolumn{2}{|c|}{ Awareness of PEP } & \multirow[b]{2}{*}{$\mathbf{X}^{2}$} & \multirow[b]{2}{*}{ P-value } \\
\hline & & Yes & No & & \\
\hline \multirow[b]{2}{*}{ Sex } & Female $=(112)$ & $81(72.3)$ & $31(27.7)$ & \multirow[b]{2}{*}{5.2} & \multirow[b]{2}{*}{0.022} \\
\hline & Male $=(139)$ & $117(84.2)$ & $22(15.8)$ & & \\
\hline \multirow{4}{*}{ Age } & $\leq 24=(43)$ & $43(100.0)$ & 0 & \multirow{4}{*}{22.6} & \multirow{4}{*}{0.001} \\
\hline & $25-34=(138)$ & $113(81.9)$ & $25(18.1)$ & & \\
\hline & $35-44=(49)$ & $34(69.4)$ & $15(30.6)$ & & \\
\hline & $\geq 45=(20)$ & $11(55)$ & $9(45)$ & & \\
\hline \multirow{7}{*}{ Educational status } & $1-10=(23)$ & $8(34.8 \%)$ & $15(65.2)$ & \multirow{7}{*}{46.3} & \multirow{7}{*}{0.000} \\
\hline & Preparatory complete $=(5)$ & $3(60.0)$ & $2(40.0)$ & & \\
\hline & Certificate $=(7)$ & $7(63.6)$ & $4(36.4)$ & & \\
\hline & Diploma $=(113)$ & $86(76.1)$ & $27(23.9)$ & & \\
\hline & First Degree $=(82)$ & $79(96.3)$ & $3(3.7)$ & & \\
\hline & Master $=(13)$ & $11(84.6)$ & $2(15.4)$ & & \\
\hline & Specialist $=(4)$ & $4(100.0)$ & 0 & & \\
\hline \multirow{6}{*}{ Current profession } & Physicians $/ \mathrm{HO}=(55)$ & $54(98.2)$ & $1(1.8)$ & \multirow{6}{*}{21.4} & \multirow{6}{*}{0.000} \\
\hline & Nurses $/$ Midwife $=(82)$ & $71(86.6)$ & $11(13.4)$ & & \\
\hline & Laboratory/ Pharmacy=(26) & $21((80.8)$ & $5(19.2)$ & & \\
\hline & Cleaner $/$ Porters $=(35)$ & $16(45.7)$ & $19(54.3)$ & & \\
\hline & Maintenance/ Laundry $=(16)$ & $10((62.5)$ & $6(37.5)$ & & \\
\hline & Others $=(37)$ & $26(70.3)$ & $11(29.7)$ & & \\
\hline \multirow{6}{*}{ Department } & $\mathrm{OPD}=(50)$ & $43(86.0)$ & $7(14.0)$ & \multirow{6}{*}{13.0} & \multirow{6}{*}{0.023} \\
\hline & Wards $=(97)$ & $84(86.6)$ & $13(13.4)$ & & \\
\hline & Theater $=(17)$ & $12(70.6)$ & $5(29.4)$ & & \\
\hline & Special clinic $=(9)$ & $7(77.8)$ & $2(22.2)$ & & \\
\hline & Maternity $=(22)$ & $17(77.3)$ & $5(22.7)$ & & \\
\hline & Others $=(56)$ & $35(62.5)$ & $21(37.5)$ & & \\
\hline \multirow{3}{*}{ Work experience } & Less5 year $=(170)$ & $145(85.3)$ & $25(14.7)$ & \multirow{3}{*}{11.5} & \multirow{3}{*}{0.003} \\
\hline & $5-10$ year $=(42)$ & $33(78.6)$ & $9(21.4)$ & & \\
\hline & Above 10 year $=(39)$ & $24(61.5)$ & $15(38.5)$ & & \\
\hline
\end{tabular}

\subsection{Association of Socio-Demographic Factor to Awareness of HIV PEP}

Assessment of Association of variables was calculated using chi square test. As a result being a female was significantly associated with awareness of PEP of HIV $\left(\mathrm{X}^{2}\right.$ $=5.2,95 \% \mathrm{CI}(\mathrm{p}=0.022)$
Younger age groups was also significantly associated with awareness of PEP than the older age groups, $\left(\mathrm{X}^{2}=22.6\right.$, $\mathrm{p}=0.001)$. Regarding educational status and professional categories, Chi-square analysis showed that strongest association was observed with being low class education status and from and non-health professionals(cleaners, porters) had poor awareness on PEP $(\mathrm{P}=0000)$. Regarding 
work experience, HCPs with low work experience less than 5 years was significantly associated with awareness and knowledge of PEP $\left(\mathrm{X}^{2}=11.5, \mathrm{p}=0.003\right)$ (Table 4)

\section{Discussion}

This study tried to assess the awareness of health care personnel towards PEP of HIV. Majority (78.9\%) of health care personnel were aware of PEP. This was higher than a study conducted in Mangalore, India which showed only $23.5 \%$ knew the first aid measures following exposure and very few of the respondents actually knew where the drugs were available at the hospital and whom to first contact following any incidence of occupational exposure (9). This was also slightly higher than other study conducted in Kenya in which $74 \%$ at rural area HCP and $67 \%$ in urban area HCP were aware of HIV PEP (10). This variation could be due to difference in attention which is given to PEP.

A study conducted among Nigerian Family physicians reveals that $97.7 \%$ of respondents were aware of the concept of post-exposure prophylaxis (11). This was in line with this study in which $98.2 \%$ physicians and health officers had awareness on PEP.

In the present study, among all study participants $87.6 \%$ have heard about PEP for HIV. It was lower as compared with a study conducted in Gondar University Hospital that shows 92.8\% participants heard about PEP (12).The difference might be due the time gap and difference in study participants.

Among health care personnel those who are a supportive staffs were less aware and knowledge about PEP of HIV in this study. This was less when comparing with others category of heath care personnel. This is similar with that of study conducted in Addis Ababa health facilities that indicates $76.6 \%$ ) health professionals were aware of PEP but this number was only $36.5 \%$ among supportive staffs (3). This study showed that $82.1 \%$ of the study participants were thinking as they are at high risk of accidental exposure to HIV infection at their work place and $25.5 \%$ had needle stick or other sharp injuries for at least onetime in their life time as well as $41.0 \%$ of them encountered blood or body fluid splash to their eye or mouth. A study conducted in Addis Ababa city health facilities also indicated that $38.2 \%$ of HCWs experienced needle stick or other sharp injuries at least one in their life time and blood and other body fluid splash in to the eye, nose and/or mouth were $34.9 \%$ respondents in their entire work career (3). Needle stick or other sharp injuries were greater than this study whereas the blood and other body fluid splash were less than the present study. This difference could be due to the study difference in population and setups.

\section{Conclusion}

Based on the finding of the study the following can be concluded:

- Majority (82.1\%) of the study participants believed as they were at a risk of acquiring HIV infection.

- About 50.6\% respondents leveled themselves as they are at high risk.

- One fourth of the respondents had needle stick or other sharp injuries at least once in their life time and $41.0 \%$ of them were encountered blood or body fluid splash to their eye or mouth.

- Majority (79.3\%) of the participants did not take any training related on how to report a needle stick injuries or other exposure.

- Respondents in younger age group and with less work experience higher awareness

- In general, the finding of this study revealed that, out of the total respondents, about $78.9 \%$ of them had good level of awareness on PEP

\section{Acknowledgement}

My sincere appreciation goes to Addis Ababa University, Department of Nursing and Midwifery and Arsi University, Department of Nursing. I wish to express my appreciation also to medical directors, department heads, head nurses and other staffs of Asella Teaching Hospital. I want also to acknowledge the data collectors, supervisors and participants for their genuine dedication and participation during the study. Finally, it gives me a great honor to thank my wife, families and best friends who gave me continuous support and inspiration throughout the study.

\section{List of Abbreviations}

AIDS Acquired Immunodeficiency Syndrome

ART Antiretroviral Therapy

ARV Antiretroviral

HCWs Health Care Workers

HIV Human Immunodeficiency Virus

PEP Post Exposure Prophylaxis

WHO World Health Organization

\section{References}

[1] Federal Ministry of Health (2011) Infection prevention and patient safety, Reference Manual for service providers and management in health care facilities of Ethiopia, Addis Ababa Ethiopia.

[2] Bosena T., Chernet H. (2010) Assessment of HIV PostExposure Prophylaxis Use Among Health Workers of Governmental Health Institutions in Jimma Zone, Oromiya Region, Southwest Ethiopia, Ethiop J Health Sci. Vol. 20, No. 1

[3] Ali S., Andrew F (2013)Prophylaxis of HIV infection, British Medical Bulletin Volume 108 Issue 1, available at ali.omrani@doctors.org.uk

[4] Tadesse A. (2008) Assessment of Health Care Workers Occupational Exposure to HIV and Post-Exposure Prophylaxis (PEP) in Health Centers and Hospitals, Addis Ababa university school of public health Addis Ababa, Ethiopia. 
[5] Ikram B., Ibtihal F., Amna M., Asma M., Emad S.(2013) Knowledge, Attitudes and Practices of Health Care Workers in Benghazi, Libya towards Post Exposure Prophylaxis for HIV. available at: http://www.ijmbs.org

[6] WHO/ILO (2005) Occupational and Non-occupational Postexposure Prophylaxis for HIV infection (HIV-PEP), Joint ILO/WHO Technical Meeting for Development of Policy and Guidelines, Ge-neva.

[7] Elizabeth H. and Philippa E.(2007) Occupational exposure to HIV and the use of post-exposure prophylaxis, Elizabeth Hamlyn, Caldecot Centre, Kings College Hospital, London SE5 9RS; 57:329-336

[8] Jayadevan S., Jayakumary M.,Manda V. (2010) Knowledge and practice of standard measures in occupational exposure to blood and body fluids among nurses in a University Hospital in the United Arab Emirates, Italian Journal of public health, JPH, 8:7.

[9] Shuvankar M., Agnihotri B., Biswanath S., Dipendra N. ,Goswami, S., Amrita S.(2013) Knowledge and Practice of
Standard Precautions and Awareness Regarding Post-Exposure Prophylaxis for HIV among Interns of a Medical College in West Bengal, India; Oman Medical Journal,Vol. 28, No. 2:141-145

[10] Samuel Omondi O,Supattra S, and Bang-on T. (2013) Awareness of occupational post-exposure prophylaxis HIV infection among health workers in Nyanza province, Kenya, Journal of public Heath and development Vol. 11 no 2 MayAugust

[11] Patricia A., Emmanuel I., Amaka N., Comfort A., Maxwell O., and Edith N. (2014) Awareness and Knowledge of human immunodeficiency virus post exposure prophylaxis among family Physicians, IP: 197.156.126.10.

[12] Biniam M., Wubet B., Sebesbe K., Meaza B., Gemechu T., Zelalem A.,Agersew A.(2013) Assessment of knowledge, attitude and practice towards post exposure prophylaxis for HIV among health care workers in Gondar, North West Ethiopia, BMC Public Health, 13:508doi:10.1186/1471-245813-508 